\title{
Competitive Fitness of Phakopsora pachyrhizi Isolates with Mutations in the CYP51 and CYTB Genes
}

\author{
Ana C. Klosowski, Lutz Brahm, Gerd Stammler, and Louise L. May De Mio
}

First and fourth authors: Universidade Federal do Paraná, Rua dos Funcionários 1540, 80035-050 Curitiba, Brazil; second and third authors: BASF SE, Fungicide Research, Agricultural Center Limburgerhof, D-67117, Germany. Accepted for publication 29 May 2016.

\begin{abstract}
Klosowski, A. C., Brahm, L., Stammler, G., and May De Mio, L. L. 2016. Competitive fitness of Phakopsora pachyrhizi isolates with mutations in the CYP51 and CYTB genes. Phytopathology 106:1278-1284.

Soybean rust (Phakopsora pachyrhizi) in Brazil is mainly controlled with applications of fungicides, including demethylation inhibitors (DMI) and quinone outside inhibitors (QoI). Isolates with less sensitivity to DMI and QoI have been reported, and these have been found to have mutations in the CYP51 and CYTB genes, respectively. There have been no reports of fitness costs in isolates with mutations in CYP51 and CYTB, and the aim of this work was to compare the competitive ability of isolates with

CYP51 or CYTB alleles were mixed and inoculated on detached soybean leaves. After 3 weeks, urediniospores were harvested and used as inoculum for the next disease cycle. Frequencies of relevant target site mutations were monitored using the pyrosequencing method over four disease cycles. Isolates with lower DMI sensitivity and different CYP51 alleles had competitive disadvantages compared with a DMI-sensitive, wild-type CYP51 isolate. In contrast, the isolate with the F129L mutation in the CYTB gene competed equally well with a QoI-sensitive, wild-type CYTB isolate under the conditions of this experiment. The CYP51 and CYTB alleles were stable in all isolates over four disease cycles when cultivated alone.
\end{abstract} lower DMI or QoI sensitivities with that of sensitive (wild-type) isolates. Urediniospores of sensitive wild-type isolates and isolates with different
Additional keywords: Asian soybean rust, fungicide resistance.
Asian soybean rust is a widespread foliar disease caused by the biotrophic fungus Phakopsora pachyrhizi Syd. \& P. Syd. (Ivancovich 2005; Pretorius et al. 2001; Schneider et al. 2005; Yorinori et al. 2005). The disease has potential to cause large reductions in soybean (Glycine max) yield and severe economic losses to soybean growers (Hartman et al. 1991; Yang et al. 1991; Yorinori et al. 2005).

Management of the disease in Brazil, where the environmental conditions are conducive to disease epidemics, is based on fungicides (Yorinori et al. 2005) and implementation of a host-free period during which farmers are restricted from planting soybean in order to reduce the quantity of primary inoculum in the main season (Seixas and Godoy 2007). In addition, the use of early-maturing soybean genotypes and early planting is recommended to avoid the most favorable environmental conditions for the development of the pathogen. Due to the genetic variability of the pathogen (Bonde et al. 2006; Freire et al. 2008) and, hence, its ability to overcome resistance genes, the use of resistant cultivars has been recommended in conjunction with the use of fungicides (Godoy 2012).

Sterol demethylation inhibitor (DMI) and quinone outsideinhibiting (QoI) fungicides are widely used for soybean rust control in South America and southern Africa, especially in mixtures (Miles et al. 2003, 2007; Scherm et al. 2009). In central Brazil, the environmental conditions can lead to early disease onset and high disease pressure. In some regions of Brazil, where is possible to have two soybean crops in the same season, up to 12 applications of those fungicides are sometimes needed in the same season, because the rust occurs in the early vegetative stages of soybean in the second crop (Godoy and Meyer 2014).

The intensive use of fungicides can result in selection for fungicide-resistant isolates. P. pachyrhizi isolates from Brazil that

Corresponding author: A. C. Klosowski; E-mail address: ana_clkl@yahoo.com.br

http://dx.doi.org/10.1094/PHYTO-01-16-0008-R

(C) 2016 The American Phytopathological Society are less sensitive to both DMI and QoI have been reported by Schmitz et al. (2014), Klosowski et al. (2016), and the Fungicide Resistance Action Committee (FRAC) (FRAC 2015). Reduced efficiency of fungicides in Brazil has been associated with lower DMI and QoI sensitivity of $P$. pachyrhizi strains (Godoy et al. 2014, 2015).

Although some resistance mechanisms function by keeping the intracellular fungicide concentration below a critical level through increased drug efflux and metabolism (Brent and Hollomon 2007; Gisi et al. 2000), the most important and best-characterized mechanism in most pathogens involves alterations in target sites due to point mutations (Chen et al. 2012; Fernández-Ortuño et al. 2008). QoI resistance is mainly related to mutations in the cytochrome $b$ (CYTB) gene (Gisi et al. 2000) and, thus far, F129L is the only mutation in $P$. pachyrhizi that is associated with QoI resistance (Klosowski et al. 2016). DMI resistance is caused by different mechanisms but mainly by mutations in the target site cytochrome P450 14 $\alpha$-sterol demethylase (CYP51) gene such as F120L, Y131H/F, K142R, and I475T, or through overexpression of CYP51, both of which have been reported in P. pachyrhizi (Schmitz et al. 2014). The enhanced efflux also might contribute to lower DMI sensitivity, as reported for Mycosphaerella graminicola (Cools and Fraaije 2013).

Resistance mutations can disrupt or reduce the efficiency of important physiological and biochemical process in the pathogen, leading to lower fitness. Fitness costs associated with fungicide resistance are often predicted but rarely reported (Zhan and McDonald 2013). Experimental evidence suggested that laboratory strains of Saccharomyces cerevisiae and Ustilago maydis azole-resistant mutants were less fit than azole-sensitive strains, implying that they would have little chance of survival in field conditions (Koller and Scheinpflug 1987). DMI resistance was associated with fitness penalties for Cercospora beticola (Karaoglanidis et al. 2001), Penicillium expansum (Karaoglanidis et al. 2011), and Monilinia fructicola (Chen et al. 2012), based on competition assays with sensitive isolates and on features such as sporulation, pathogenicity, and mycelium growth, whereas no fitness cost was observed for 
DMI-resistant isolates of Pyrenophora teres (Peever and Milgroom 1994). The association between QoI resistance and fitness penalties is not well elucidated but it has been suggested that the mutations of resistant isolates affect the fitness of plant pathogens differentially (Fernández-Ortuño et al. 2008). Fitness costs of QoI resistance have been described earlier for Botrytis cinerea (Kim and Xiao 2011) and Plasmopara viticola (Toffolatti et al. 2007). The F129L mutation, which has been reported in some Phakopsora pachyrhizi isolates (Klosowski et al. 2016), was associated with fitness costs for Alternaria solani, based on competition assays between field-mutated and wild-type isolates (Pasche and Gudmestad 2008).

For optimized resistance management strategies, it is of importance to characterize the fitness costs in mutated strains (Mikaberidze and McDonald 2015). Resistant isolates with lower fitness tend to have competitive disadvantages compared with sensitive isolates in the absence of the fungicide. Thus, reducing the total number of applications, alternating with noncross-resistant fungicides, and using mixtures of noncross-resistant fungicides can favor a decline of resistant strains that have a fitness deficit (Brent and Hollomon 2007; Mikaberidze and McDonald 2015). In a first approach, we investigated whether fitness costs are connected with the F120L, $\mathrm{Y} 131 \mathrm{~F} / \mathrm{H}, \mathrm{K} 142 \mathrm{R}$, or I475T mutations in the CYP51 gene or the F129L mutation in the CYTB gene. Competition trials were used in which nontreated and wild-type strains were mixed, inoculated, harvested, and inoculated again over four disease cycles. This was done under optimal growth conditions and under stress conditions by using sublethal doses of the multisite fungicide mancozeb. The stability of the mutations in the various isolates was examined by cultivation of single strains on soybean leaves over four cycles.

\section{MATERIALS AND METHODS}

P. pachyrhizi isolates. Monouredinial isolates of $P$. pachyrhizi were obtained from the BASF SE (Limburgerhof, Germany) collection. The isolates with mutations in the CYP51 gene were collected in different regions of Brazil during the 2009-10 growing season, and the mutations were previously characterized by Schmitz et al. (2014). The isolate with a mutation in the CYTB gene was collected in Brazil during the 2013-14 growing season, and the F129L mutation was characterized by the BASF SE group. The isolates are further described in Table 1.

To multiply the inoculum, spore suspensions prepared in water with Tween $(0.01 \%)$ were inoculated on the abaxial surface of unifoliolate leaves of 'ES Mentor' soybean (Saatbau, Linz, Austria) using an airbrush (0.3-mm nozzle). The leaves were kept in petri dishes containing water agar medium $(1 \%)$ with kinetin $(0.2 \mathrm{mg}$ liter $^{-1}$ ) and streptomycin sulfate $\left(30 \mathrm{mg} \mathrm{liter}^{-1}\right)$. After inoculation, the leaves were kept in the dark for $24 \mathrm{~h}$ at room temperature, followed by $12 \mathrm{~h}$ of light at $23^{\circ} \mathrm{C}$. Every 3 weeks, the spores were transferred to new leaves.

DNA extraction. The DNA was extracted from urediniospores of seven P. pachyrhizi isolates (Table 1) using the NucleoSpin DNA Plant II Kit following the instructions of the manufacturer for cetyltrimethylammonium bromide-based DNA extraction (MachereyNagel GmbH \& Co. KG, Düren, Germany). The urediniospores used for DNA extraction were stored in a freezer at $80^{\circ} \mathrm{C}$.

Pyrosequencing assay. To confirm the presence and abundance of the mutations in the isolates, a pyrosequencing assay was carried out using the primers and methods described by Schmitz et al. (2014) and Klosowski et al. (2016). The point mutations F120L, Y131F, Y131H, K142R, and I475T in the CYP51 gene and F129L in the CYTB gene were analyzed. In a first step, the gene fragment, which contained the target sequence, was amplified in polymerase chain reaction (PCR) using $12.5 \mu$ of $2 \times$ Maxima Mastermix (Fermentas GmbH St., Leon-Rot, Germany), $7.5 \mu \mathrm{l}$ of bidistilled water, $2.5 \mu \mathrm{l}$ of DNA, and $1.25 \mu \mathrm{l}$ of each PCR primer. The conditions of the reaction were an initial heating step for $4 \mathrm{~min}$ at $95^{\circ} \mathrm{C}$; followed by 40 cycles of $15 \mathrm{~s}$ at $94^{\circ} \mathrm{C}, 30 \mathrm{~s}$ at $55^{\circ} \mathrm{C}$, and $15 \mathrm{~s}$ at $72^{\circ} \mathrm{C}$; and a final step of $5 \mathrm{~min}$ at $72^{\circ} \mathrm{C}$. Every template was run in duplicate. The pyrosequencing reaction was performed for sequence determination and allele quantification using PyroMark Gold Q96 reagents (Qiagen, Hilden, Germany) on a PSQ 96MA (Qiagen) machine, as described by the manufacturer, and the analysis of results was performed using the Pyrosequencing Assay Design software (Qiagen). For single-strand preparation, PCR products were immobilized on Streptavidin Sepharose beads (GE Healthcare, Little Chalfont, Bucks, UK) and cleaned up with ethanol (70\%), denaturated with sodium hydroxide $(0.2 \mathrm{M})$, and washed in Trisacetate $(10 \mathrm{mM})$. Then, the samples were released into a mixture of annealing buffer with the specific sequencing primer for each region of both genes, implementing the Vacuum Prep Worktable (Qiagen), following the instructions of the manufacturer. Next, the samples were heated at $80^{\circ} \mathrm{C}$ for $3 \mathrm{~min}$ in an incubator and cooled to room temperature before they were submitted to the pyrosequencing reaction.

Isolates and their mutations are described in Table 1, where $S$ indicates the wild-type for the specific regions analyzed in the CYP51 and CYTB genes; $M$ indicates a mutation in CYP51 or CYTB; and M1, M2, M3, and M4 describe different CYP51 or CYTB alleles.

Stress caused by multisite fungicide. Unifoliolate leaves pretreated with mancozeb were used in the fitness assays to verify the behavior of $P$. pachyrhizi isolates under stress conditions caused by this multisite fungicide. Mancozeb belongs to the dithiocarbamate group, with multisite contact activity. This group is considered by FRAC to be a low risk regarding the development of resistant pathogens. Mancozeb was chosen for this experiment because it is the only multisite fungicide registered with the Ministry of Agriculture for control of soybean rust in Brazil (MAPA 2016). Therefore, mancozeb was sprayed on soybean plants 1 day before inoculation at $50 \mathrm{mg}$ liter $^{-1}$, which was determined in a previous sensitivity test to be the concentration causing $40 \%$ inhibition of rust severity in detached leaves (data not shown).

Competition assay. Mutations in the CYP51 gene. The suspensions of urediniospores were prepared in water with Tween $(0.01 \%)$ for each isolate and were adjusted to $2.5 \times 10^{4}$ urediniospores $\mathrm{ml}^{-1}$. Mixtures of a sensitive isolate (8) and mutated isolates $(72,62$, 63,27 , and 28) were made as follows: $20 \% \mathrm{~S}+80 \% \mathrm{M} 1,20 \% \mathrm{~S}+$ $80 \% \mathrm{M} 2,20 \% \mathrm{~S}+80 \% \mathrm{M} 3$, according to the isolate type in Table 1. Mixtures of two isolates were used for the mutations M2 (isolates 62 and 63) and M3 (isolates 27 and 28) (Table 1). Because the frequencies of the relevant CYP51 mutations in P. pachyrhizi were approximately 30 and 50\% (Schmitz et al. 2014), mixtures with the proportion $50 \%$ sensitive isolate $+50 \%$ mutant isolates were not used because the detection limit of pyrosequencing assay is approximately $5 \%$. Therefore, approximately $80 \%$ of mutated isolates in the mixture

TABLE 1. Isolates of Phakopsora pachyrhizi of Brazil, seasons 2009-10 and 2013-14, and their mutations in cytochrome P450 14 $\alpha$-sterol demethylase (CYP51) and cytochrome $b$ (CYTB) genes ${ }^{\mathrm{a}}$

\begin{tabular}{|c|c|c|c|c|c|}
\hline \multirow[b]{2}{*}{ Isolate } & \multirow[b]{2}{*}{ Location } & \multirow[b]{2}{*}{ Season } & \multicolumn{2}{|c|}{ Mutation $^{\mathrm{b}}$} & \multirow[b]{2}{*}{$\begin{array}{l}\text { Isolate } \\
\text { type }^{\mathrm{c}}\end{array}$} \\
\hline & & & $\begin{array}{c}\text { CYP51 } \\
\text { gene }\end{array}$ & $\begin{array}{l}\text { CYTB } \\
\text { gene }\end{array}$ & \\
\hline $8^{d}$ & Goiás & $2009-10$ & Wild type & Wild type & $S$ \\
\hline $72^{\mathrm{d}}$ & Paraná & $2009-10$ & $\mathrm{~F} 120 \mathrm{~L}+\mathrm{Y} 131 \mathrm{H}$ & Wild type & M1 \\
\hline $62^{\mathrm{d}}$ & Goiás & $2009-10$ & $\mathrm{Y} 131 \mathrm{~F}+\mathrm{K} 142 \mathrm{R}$ & Wild type & M2 \\
\hline $63^{\mathrm{d}}$ & Goiás & $2009-10$ & $\mathrm{Y} 131 \mathrm{~F}+\mathrm{K} 142 \mathrm{R}$ & Wild type & M2 \\
\hline $27^{\mathrm{d}}$ & Goiás & $2009-10$ & $\mathrm{Y} 131 \mathrm{~F}+\mathrm{I} 475 \mathrm{~T}$ & Wild type & M3 \\
\hline $28^{\mathrm{d}}$ & Goiás & $2009-10$ & $\mathrm{Y} 131 \mathrm{~F}+\mathrm{I} 475 \mathrm{~T}$ & Wild type & M3 \\
\hline GWH-Be & São Paulo & 2013-14 & $\mathrm{F} 120 \mathrm{~L}+\mathrm{Y} 131 \mathrm{H}$ & F129L & M4 \\
\hline
\end{tabular}

a All isolates belong to the BASF SE collection.

b Wild type means that the mutations tested were not detected.

c $\mathrm{S}=$ sensitive isolate and M1, M2, M3, and M4 = different alleles with mutations in CYP51 or CYTB genes.

d Isolates with mutations described by Schmitz et al. (2014).

e Isolate with mutations characterized by BASF SE group. 
were targeted for a reliable monitoring of the frequency of mutations over the disease cycles.

The urediniospore suspension was inoculated using the same procedure as described earlier for inoculum multiplication. For each mixture, six nontreated leaves and six mancozeb-pretreated leaves of 'ES Mentor' (Saatbau) were inoculated. After 21 days of incubation, pieces of the leaves with sporulating pustules were placed in $5 \mathrm{ml}$ of water with Tween $(0.01 \%)$ and shaken to release the spores. The resulting suspension was used to inoculate new leaves $(3 \mathrm{ml})$, starting a new disease cycle, and to extract DNA $(2 \mathrm{ml})$ for the subsequent pyrosequencing assay. The procedure was repeated after every disease cycle and the experiment was terminated after four cycles.

Mutation in the CYTB gene. This experiment involved three isolates: 8 (S), GWH-B (M4), and 72 (M1). Mixtures were made as follows: $50 \% \mathrm{~S}+50 \% \mathrm{M} 4,20 \% \mathrm{~S}+80 \% \mathrm{M} 4,50 \% \mathrm{M} 1+50 \% \mathrm{M} 4$, and $20 \% \mathrm{M} 1+80 \% \mathrm{M} 4$, as designated in Table 1 .

The procedures of this experiment were the same as described for the competition assay for mutations in the CYP51 gene. In this case, the pyrosequencing always showed the frequency of the F129L mutation in the CYTB gene to be $100 \%$ (Klosowski et al. 2016). Therefore, it was possible to use the proportions $50 \%$ sensitive isolate $+50 \%$ mutated isolate and $20 \%$ sensitive isolate $+80 \%$ mutated isolate without compromising the quantification of the mutation in the mixture.

Quantification of the resistance allele using pyrosequencing. To quantify the frequency of mutations in the isolates and mixtures, the pyrosequencing assay was done at the outset of the experiment and after every disease cycle, following the procedures described by Schmitz et al. (2014) and Klosowski et al. (2016).

Determination of the stability of the mutations. To determine the stability of mutations in isolates during the life cycles of the fungus, suspensions of urediniospores were made in water with Tween $(0.01 \%)$ for each isolate and they were adjusted to $2.5 \times 10^{4}$ urediniospores $\mathrm{ml}^{-1}$. Single isolates were inoculated on four nontreated leaves and four mancozeb-pretreatred leaves. The same procedures for urediniospore transfer and pyrosequencing analysis

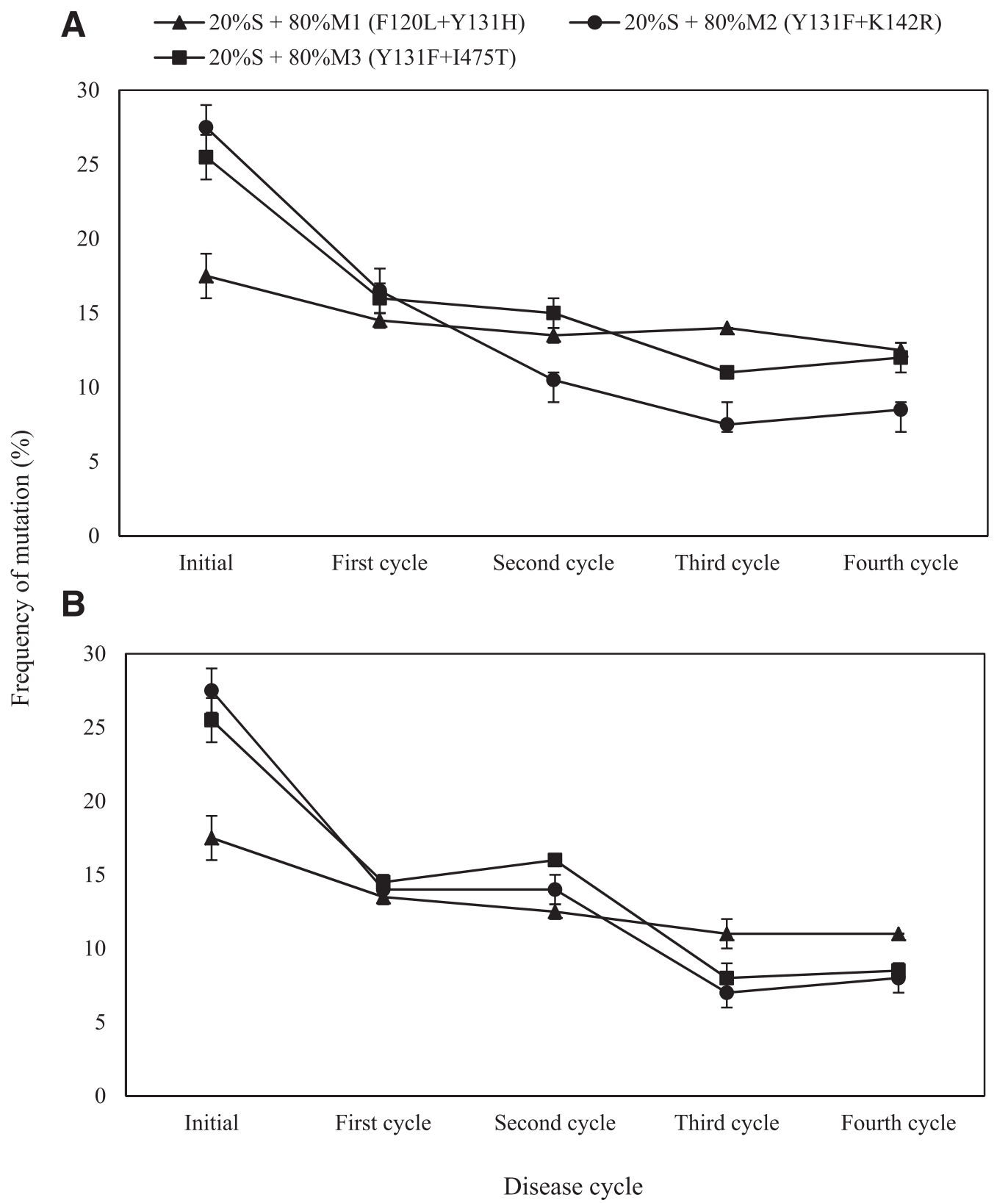

Fig. 1. Frequency of mutations in cytochrome P450 14 $\alpha$-sterol demethylase (CYP51) gene in competition assays between sensitive (S = wild type) and mutated isolates $(\mathrm{M} 1=\mathrm{F} 120 \mathrm{~L}+\mathrm{Y} 131 \mathrm{H}, \mathrm{M} 2=\mathrm{Y} 131 \mathrm{~F}+\mathrm{K} 142 \mathrm{R}$, and M3 $=\mathrm{Y} 131 \mathrm{~F}+\mathrm{I} 475 \mathrm{~T})$ of Phakopsora pachyrhizi during four disease cycles on A, nontreated and B, mancozeb-pretreated soybean leaves. Vertical lines indicate the standard error of the mean. 
described above were made after every cycle and the experiment was completed after four cycles. The assay was performed twice.

Data analysis. In the competition assays, the frequency of resistant isolates in the last disease cycle was compared with the initial frequency by the pairwise Student's $t$ test. The same test was used to determine the stability of the mutations, comparing the frequency of mutations for single isolates in the last cycle with their initial frequency. The data analysis was performed using the statistical software R (R Development Core Team, Vienna).

\section{RESULTS}

Competition assay. Mutations in the CYP51 gene. The frequency of isolates with CYP51 mutations decreased in the mixtures with the wild-type isolate after four disease cycles $(P \leq 0.01)$ on both nontreated leaves and mancozeb-pretreated leaves (Fig. 1).

The decrease was higher for the Y131F + K142R and Y131F + I475T mutations than for the F120L + Y131H mutation (Fig. 1). For the $\mathrm{Y} 131 \mathrm{~F}+\mathrm{K} 142 \mathrm{R}$ mutation, the frequency of resistant isolates declined from 27 to $8 \%$ on both nontreated leaves and mancozebpretreated leaves. For the Y131F + I475T mutation, the proportion declined from 26 to $12 \%$ on nontreated leaves and to $8 \%$ in mancozeb-pretreated leaves. For the F120L + Y131H mutation, the frequency decreased from 17 to 12 and $11 \%$ on nontreated and mancozeb-pretreated leaves, respectively.

Mutation in the CYTB gene. The frequency of isolate GWH-B with the F129L mutation after four disease cycles was not different from the initial frequency $(P \leq 0.01)$ in the mixture with sensitive isolate 8 on both nontreated and mancozeb-pretreated leaves. In

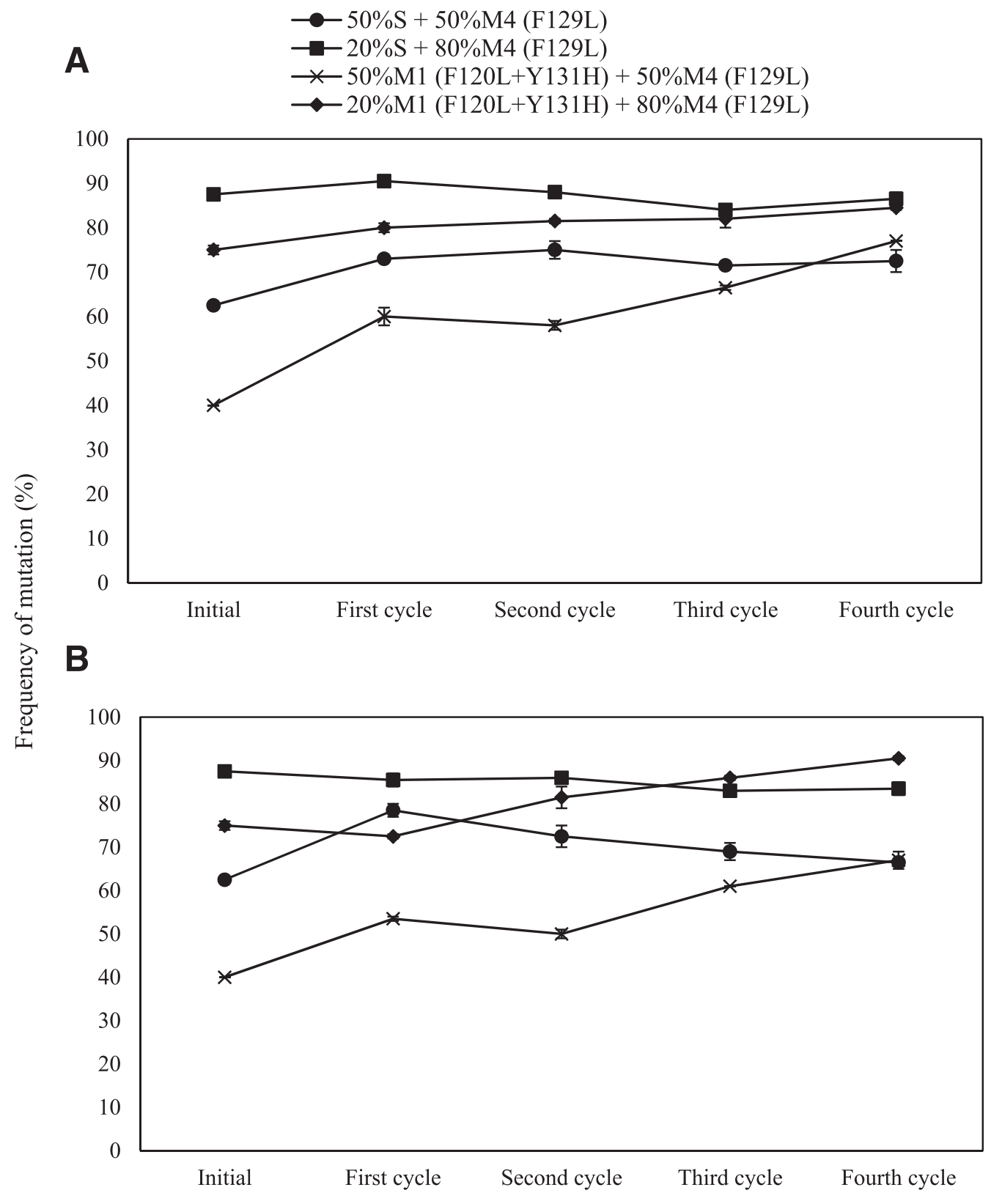

Disease cycle

Fig. 2. Frequencies of mutations in cytochrome $b(\mathrm{CYTB})$ gene in competition assays between sensitive $(\mathrm{S}=$ wild type $)$ and mutated isolates $(\mathrm{M} 1=\mathrm{F} 120 \mathrm{~L}+$ Y131H in cytochrome P450 14 $\alpha$-sterol demethylase gene [CYP51] and F129L in CYTB gene and M4 = F120L + Y131H in CYP51) of Phakopsora pachyrhizi during four disease cycles on $\mathbf{A}$, nontreated and $\mathbf{B}$, mancozeb-pretreated soybean leaves. Vertical lines indicate the standard error of the mean. 
the mixture of isolates GWH-B and 72, the frequency of the first increased during the four disease cycles in both the 50\% M1+50\% M4 and the $20 \% \mathrm{M} 1+80 \% \mathrm{M} 4$ proportions, and the results were similar for nontreated and treated leaves (Fig. 2).

Determination of the stability of the mutations. The frequency of relevant mutations in CYP51 and CYTB genes was stable during four disease cycles for all isolates of $P$. pachyrhizi on both nontreated and mancozeb-pretreated leaves (Fig. 3). The frequency of the F129L mutation in the CYTB gene was $100 \%$ but all mutations in the CYP51 gene showed a frequency between approximately 20 and $50 \%$.

\section{DISCUSSION}

The mutations in both the CYP51 and CYTB genes were stable in isolates when each isolate was cultured alone on the detached soybean leaves over four disease cycles. According to the pyrosequencing analysis, the frequencies of the relevant CYP51 mutations in P. pachyrhizi were not $100 \%$ as the frequency of the F129L mutation in the CYTB gene, indicating that more than one copy of the CYP51 gene exists in the genome of $P$. pachyrhizi and that mutations occur in some but not all copies (Schmitz et al. 2014). This was observed for some filamentous fungi, particularly Ascomycetes, which often possess two or more CYP51 paralogues, and the changes can occur in just one paralogue (Fan et al. 2013). Another factor that can be considered is the dikaryotic nature of the urediospores of rust fungi, which means that these organisms maintain two genetically distinct haploid nuclei separately.

In addition to the biological meaning of the stability of the mutations (that the mutation is transmitted to the next generations), this finding is important to confirm that the pyrosequencing method is a reliable method to quantify mutations.

Isolates with lower DMI sensitivity and three different CYP51 alleles had competitive disadvantages compared with the fungicidesensitive isolate with the wild-type CYP51 gene. The isolate with the F129L mutation in the CYTB gene competed equally well with the sensitive isolate with the wild-type CYTB gene under the conditions of this experiment.

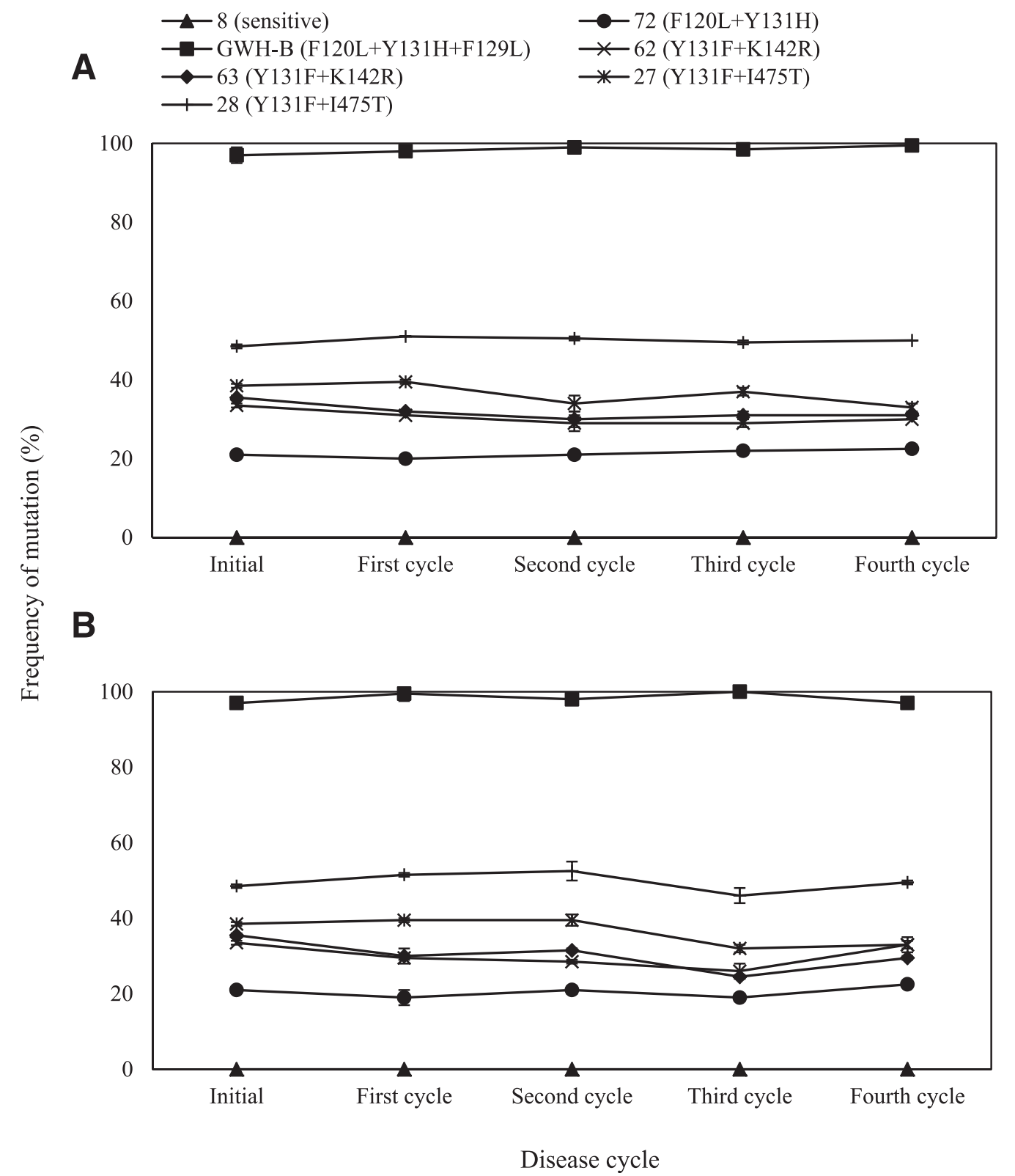

Fig. 3. Frequencies of mutations in cytochrome $b$ (CYTB) gene (isolate GWH-B) and in cytochrome P450 14 $\alpha$-sterol demethylase (CYP51) gene (other isolates) in isolates of Phakopsora pachyrhizi during four disease cycles on A, nontreated and $\mathbf{B}$, mancozeb-pretreated soybean leaves. Vertical lines indicate the standard error of the mean. Values shown are means from two independent experiments. 
Mancozeb did not have an effect on the dynamics of competition between the wild-type isolate and isolates with mutations in the CYP51 and CYTB genes. Although a lower number of rust lesions has generally been observed on mancozeb-treated leaves compared with nontreated leaves (data not shown), the sensitivity of wild-type and mutant isolates appeared to be similar because the frequency of isolates in the mixtures was the same in the presence or absence of multisite fungicide, indicating that all isolates were inhibited equally well by mancozeb.

A more significant competitive disadvantage was observed for CYP51 alleles Y131F + I475T and Y131F + K142R than for F120L + Y131H. According to Schmitz et al. (2014), the occurrence of $\mathrm{Y} 131 \mathrm{~F}+\mathrm{I} 475 \mathrm{~T}$ and $\mathrm{Y} 131 \mathrm{~F}+\mathrm{K} 142 \mathrm{R}$ combinations is related to higher effective dose which reduces population activity by $50 \%$ $\left(\mathrm{ED}_{50}\right)$ values, whereas a larger range of $\mathrm{ED}_{50}$ values was observed in the presence of the $\mathrm{F} 120 \mathrm{~L}+\mathrm{Y} 131 \mathrm{H}$ combination, ranging from 0.06 to $10.0 \mathrm{mg} \mathrm{liter}^{-1}$. Similar results were found for C. beticola, in which the frequency of the resistant isolate decreased significantly after four disease cycles in comparisons of DMI-resistant and -sensitive isolates in the greenhouse. Moreover, in the field, results showed that, at the end of the growing period, the frequency of the resistant isolates had decreased slightly $(P \leq 0.05)$ (Karaoglanidis et al. 2001). The same tendency was found for M. fructicola after nine transfer cycles on acidified potato dextrose agar (Lichtemberg 2015). The frequency of resistant isolates decreased in the absence of fungicide in all of these experiments although, even after many pathogen cycles, they had not been eliminated from the population.

Studies involving pathogens such as M. fructicola, A. alternata, and Pyrenophora teres that evaluated parameters related to fitness such as mycelial growth rate, latent period, spore production, spore germination, and pathogenicity showed conflicting results about the relationship between resistance to DMI and fitness costs (Chen et al. 2012; Karaoglanidis et al. 2011; Peever and Milgroom 1994).

The competitive disadvantage of $P$. pachyrhizi isolates with CYP51 mutations relative to sensitive isolates with the wild-type CYP51 sequence might be useful for resistance management strategies if this is confirmed in the field. Selection of resistant isolates is determined by selection pressure of the fungicide on the one hand and by fitness costs connected with resistance on the other. Practices that reduce selection pressure such as limited numbers of fungicide applications and the alternation and mixing of fungicide chemistries with different modes of action should be implemented in disease control strategies. Monitoring of DMI sensitivity is essential to assess the usefulness of these strategies. Because FRAC reports the DMI sensitivity situation as more or less stable (FRAC 2015), the current resistance management strategies seem to be efficient in preventing a further shift of the population to lower DMI sensitivities.

In contrast to the changes observed with the CYP51 mutants, there were no fitness costs detectable for the P. pachyrhizi strain with the F129L mutation in the CYTB gene versus the strain with the wild-type CYTB gene. It is important to keep in mind that isolate GWH-B contains the mutation F120L + Y131H in the CYP51 gene in addition to the F129L mutation in the CYTB gene. This mutation in the CYP51 gene was associated with fitness penalties, which indicates that the F129L mutation, also present in isolate GWH-B, may be associated with an increased fitness, because isolate GWH-B had a competitive advantage when it was cultured with isolate 72 that just showed the mutation in the CYP51 gene. However, this effect can be demonstrated by testing isolates containing only the F129L mutation in the CYTB gene.

The newest internal monitoring data indicate moderate to high levels of F129L in the soybean rust populations from different regions of Brazil (data not shown), which indicates a relatively rapid increase in the abundance of this mutation. However, our studies on F129L fitness costs were performed with only one mutated isolate. It is possible that other properties, independent of the F129L mutation, might have influenced this outcome. Therefore, the results found for this set of isolates are an indication of situations that can happen in the field, and more extensive competition studies involving a larger number of resistant and sensitive isolates might be conducted to confirm these results. Learning more about properties such as viability of urediniospores, temperature tolerance, incubation period, and virulence on other hosts could also be important objectives of future fitness studies.

It will be interesting to monitor whether the use of succinate dehydrogenase inhibitors, which have been recently introduced as potent fungicides for soybean rust control, will reduce selection pressure of DMI and QoI, and will lead to a decrease in the frequency of mutant CYP51 and CYTB genes in field populations.

\section{ACKNOWLEDGMENTS}

A. C. Klosowski received a PDSE scholarship from CAPES (Brazil). We thank S. Miessner for excellent technical assistance and K. Simões and R. Rodrigues for providing samples and fruitful discussions.

\section{LITERATURE CITED}

Bonde, M. R., Nester, S. E., Austin, C. N., Stone, C. L., Frederick, R. D., Hartman, G. L., and Miles, M. R. 2006. Evaluation of virulence of Phakopsora pachyrhizi and P. meibomiae isolates. Plant Dis. 90:708-716.

Brent, K. J., and Hollomon, D. W. 2007. Fungicide Resistance in Crop Pathogens: How Can it be Managed? 2nd revised ed. Fungicide Resistance Action Committee, Brussels.

Chen, F. P., Fan, J. R., Zhou, T., Liu, X. L., Liu, J. L., and Schnabel, G. 2012. Baseline sensitivity of Monilinia fructicola from China to the DMI fungicide SYP-Z048 and analysis of DMI-resistant mutants. Plant Dis. 96:416-422.

Cools, H. J., and Fraaije, B. A. 2013. Update on mechanisms of azole resistance in Mycosphaerella graminicola and implications for future control. Pest Manage. Sci. 69:150-155.

Fan, J., Urban, M., Parker, J. E., Brewer, H. C., Kelly, S. L., Hammond-Kosack, K. E., Fraaije, B. A., Liu, X., and Cools, H. J. 2013. Characterization of the sterol $14 \alpha$-demethylases of Fusarium graminearum identifies a novel genusspecific CYP51 function. New Phytol. 198:821-835.

Fernández-Ortuño, D., Torés, J. A., De Vicente, A., and Pérez-García, A. 2008. Mechanisms of resistance to QoI fungicides in phytopathogenic fungi. Int. Microbiol. 11:1-9.

FRAC. 2015. Mutations associated with QoI-resistance. Online publication. http:// www.frac.info/docs/default-source/about-frac/mutations-associated-with-qoiresistance.pdf

Freire, M. C. M., de Oliveira, L. O., de Almeida, A. M. R., Schuster, I., Moreira, M. A., Liebenberg, M. M., and Mienie, C. M. S. 2008. Evolutionary history of Phakopsora pachyrhizi (the Asian soybean rust) in Brazil based on nucleotide sequences of the internal transcribed spacer region of the nuclear ribosomal DNA. Genet. Mol. Biol. 31:920-931.

Gisi, U., Chin, K. M., Knapova, G., Kung Farber, R., Mohr, U., Parisi, S., Sierotzki, H., and Steinfeld, U. 2000. Recent developments in elucidating models of resistance to phenylamide, DMI and strobilurin fungicides. Crop Prot. 19:863-872.

Godoy, C. V. 2012. Risk and management of fungicide resistance in the Asian soybean rust fungus Phakopsora pachyrhizi. Pages 87-95 in: Fungicide Resistance in Crop Protection: Risk and Management. T. S. Thind, ed. CAB International, Wallingford, UK.

Godoy, C. V., and Meyer, M. C. 2014. Resistência a fungicidas na cultura da soja. Informativo Meridional, 51. Online publication. http://www.fundacaomeridional. com.br/informativos/2015

Godoy, C. V., Utiamada, C. M., Meyer, M. C., Campos, H. D., Forcelini, C. A., and Pimenta, C. B. 2015. Eficiência de fungicidas para o controle da ferrugemasiática da soja, Phakopsora pachyrhizi, na safra 2014/15: Resultados sumarizados dos ensaios cooperativos. Circ. Téc. 111. Embrapa, Londrina, Brasil.

Godoy, C. V., Utiamada, C. M., Meyer, M. C., Campos, H. D., Pimenta, C. B., and Cassetari Neto, D. 2014. Eficiência de fungicidas para o controle da ferrugemasiática da soja, Phakopsora pachyrhizi, na safra 2013/14: Resultados sumarizados dos ensaios cooperativos. Circ. Téc. 103. Embrapa, Londrina, Brasil.

Hartman, G. L., Wang, T. C., and Tschanz, A. T. 1991. Soybean rust development and the quantitative relationship between rust severity and soybean yield. Plant Dis. 75:596-600.

Ivancovich, A. 2005. Soybean rust in Argentina. Plant Dis. 89:667-668

Karaoglanidis, G. S., Luo, Y., and Michailides, T. J. 2011. Competitive ability and fitness of Alternaria alternata isolates resistant to QoI fungicides. Plant Dis. 95:178-182.

Karaoglanidis, G. S., Thanassoulopoulos, C. C., and Ioannidis, P. M. 2001. Fitness of Cercospora beticola field isolates resistant and sensitive to demethylation inhibitor fungicides. Eur. J. Plant Pathol. 107:337-347. 
Kim, Y. K., and Xiao, C. L. 2011. Stability and fitness of pyraclostrobin- and boscalid-resistant phenotypes in field isolates of Botrytis cinerea from apple. Phytopathology 101:1385-1391.

Klosowski, A. C., May De Mio, L. L., Miessner, S., Rodrigues, R., and Stammler, G. 2016. Detection of the F129L mutation in the cytochrome $b$ gene in Phakopsora pachyrhizi. Pest Manage. Sci. 72:1211-1215.

Koller, W., and Scheinpflug, H. 1987. Fungal resistance to sterol biosynthesis inhibitors: A new challenge. Plant Dis. 71:1066-1074.

Lichtemberg, P. S. F. 2015. Dynamics and stability of resistance to tebuconazole in Monilinia fructicola populations from Brazilian peach orchards. Ph.D. thesis, Universidade Federal do Paraná (Federal University of Paraná), Curitiba, Brazil.

MAPA. 2016. Agrofit-Phytosanitary pesticides system. Online publication. http://agrofit.agricultura.gov.br/agrofit_cons/principal_agrofit_cons

Mikaberidze, A., and McDonald, B. A. 2015. Fitness cost of resistance: Impact on management. Pages 77-89 in: Fungicide Resistance in Plant Pathogens. H. Ishii and D. W. Hollomon, eds. Springer, Tokyo.

Miles, M. R., Hartman, G. L., Levy, C., and Morel, W. 2003. Current status of soybean rust control by fungicides. Pestic. Outlook 14:197-200.

Miles, M. R., Levy, C., Morel, W., Mueller, T., Steinlage, T., Rij, N., Frederick, R. D., and Hartman, G. L. 2007. International fungicide efficacy trials for the management of soybean rust. Plant Dis. 91: 1450-1458.

Pasche, J. S., and Gudmestad, N. C. 2008. Prevalence, competitive fitness and impact of the F129L mutation in Alternaria solani from the United States. Crop Prot. 27:427-435.

Peever, T. L., and Milgroom, M. G. 1994. Lack of correlation between fitness and resistance to sterol biosynthesis-inhibiting fungicide in Pyrenophora teres. Phytopathology 84:515-519.
Pretorius, Z. A., Kloppers, F. J., and Frederick, R. D. 2001. First report of soybean rust in South Africa. Plant Dis. 85:1288.

Scherm, H., Christiano, R. S. C., Esker, P. D., Del Ponte, E. M., and Godoy, C. V. 2009. Quantitative review of fungicide efficacy trials for managing soybean rust in Brazil. Crop Prot. 28:774-782.

Schmitz, H. K., Medeiros, C. A., Craig, I. R., and Stammler, G. 2014. Sensitivity of Phakopsora pachyrhizi towards quinone-outside-inhibitors and demethylation-inhibitors, and corresponding resistance mechanisms. Pest Manage. Sci. 70:378-388.

Schneider, R. W., Holier, C. A., Whitam, H. K., Palm, M. E., McKemy, J. M., Hernandez, J. R., Levy, L., and DeVries-Paterson, R. 2005. First report of soybean rust caused by Phakopsora pachyrhizi in the continental United States. Plant Dis. 89:774.

Seixas, C. D. S., and Godoy, C. V. 2007. Vazio sanitário: Panorama nacional e medidas de monitoramento. Pages 23-33 in: Anais do simpósio brasileiro de ferrugem asiática da soja. EMBRAPA - Brazilian Agricultural Research Institute, Londrina, Brasil.

Toffolatti, S. L., Serrati, L., Sierotski, H., Gisi, U., and Vercesi, A. 2007. Assessment of QoI resistance in Plasmopara viticola oospores. Pest Manage. Sci. 63:194-201.

Yang, X. B., Tschanz, A. T., Dowler, W. M., and Wang, T. C. 1991. Development of yield loss models in relation to reductions of components of soybean infected with Phakopsora pachyrhizi. Phytopathology 81:1420-1426.

Yorinori, J. T., Paiva, W. M., Frederick, R. D., Costamilan, L. M., Bertagnolli, P. F., Hartman, G. E., Godoy, C. V., and Nunes, J., Jr. 2005. Epidemics of soybean rust (Phakopsora pachyrhizi) in Brazil and Paraguay from 2001 to 2003. Plant Dis. 89:675-677.

Zhan, J., and McDonald, B. A. 2013. Experimental measures of pathogen competition and relative fitness. Annu. Rev. Phytopathol. 51:131-153. 